Article

\title{
Preparation of Magnetic $\mathrm{CuFe}_{2} \mathrm{O}_{4} @ \mathrm{Ag} @ \mathrm{ZIF}-8$ Nanocomposites with Highly Catalytic Activity Based on Cellulose Nanocrystals
}

\author{
Sufeng Zhang ${ }^{1, *(\mathbb{D})}$, Yongshe $\mathrm{Xu}^{1,2}$, Dongyan Zhao ${ }^{1}$, Wenqiang Chen ${ }^{1}, \mathrm{Hao} \mathrm{Li}^{1}$ and Chen Hou ${ }^{1}$ \\ 1 College of Bioresources Chemical and Materials Engineering, Shaanxi University of Science and Technology, \\ Shaanxi Provincial Key Laboratory of Papermaking Technology and Specialty Paper Development, \\ Key Laboratory of Paper Based Functional Materials of China National Light Industry, National \\ Demonstration Center for Experimental Light Chemistry Engineering Education, Xi'an 710021, China; \\ zgyczbzgs@126.com (Y.X.); 15991346475@163.com (D.Z.); cwq1801075@163.com (W.C.); \\ lihao120733@163.com (H.L.); houchen@sust.edu.cn (C.H.) \\ 2 Tianjin China Banknote Paper Co., Ltd., Tianjin 300385, China \\ * Correspondence: zhangsufeng@sust.edu.cn; Tel.: +86-15091096432
}

Academic Editors: Alireza Ghiasvand and Joselito P. Quirino

Received: 23 November 2019; Accepted: 18 December 2019; Published: 28 December 2019

check for updates

\begin{abstract}
A facile approach was successfully developed for synthesis of cellulose nanocrystals (CNC)-supported magnetic $\mathrm{CuFe}_{2} \mathrm{O}_{4} @ \mathrm{Ag} @ \mathrm{ZIF}-8$ nanospheres which consist of a paramagnetic $\mathrm{CuFe}_{2} \mathrm{O}_{4} @ \mathrm{Ag}$ core and porous ZIF- 8 shell. The $\mathrm{CuFe}_{2} \mathrm{O}_{4}$ nanoparticles (NPs) were first prepared in the presence of $\mathrm{CNC}$ and dispersant. Ag NPs were then deposited on the $\mathrm{CuFe}_{2} \mathrm{O}_{4} / \mathrm{CNC}$ composites via an in situ reduction directed by dopamine polymerization (PDA). The $\mathrm{CuFe}_{2} \mathrm{O}_{4} / \mathrm{CNC} @ \mathrm{Ag} @ \mathrm{ZIF}-8$ nanocomposite was characterized by TEM, FTIR, XRD, $\mathrm{N}_{2}$ adsorption-desorption isotherms, VSM, and XPS. Catalytic studies showed that the $\mathrm{CuFe}_{2} \mathrm{O}_{4} / \mathrm{CNC} @ \mathrm{Ag} @ \mathrm{ZIF}-8$ catalyst had much higher catalytic activity than $\mathrm{CuFe}_{2} \mathrm{O}_{4} @ \mathrm{Ag}$ catalyst with the rate constant of $0.64 \mathrm{~min}^{-1}$. Because of the integration of ZIF-8 with $\mathrm{CuFe}_{2} \mathrm{O}_{4} / \mathrm{CNC@Ag}$ that combines the advantaged of each component, the nanocomposites were demonstrated to have an enhanced catalytic activity in heterogeneous catalysis. Therefore, these results demonstrate a new method for the fabrication of CNC-supported magnetic core-shell catalysts, which display great potential for application in biocatalysis and environmental chemistry.
\end{abstract}

Keywords: $\mathrm{CuFe}_{2} \mathrm{O}_{4}$ nanoparticles; cellulose nanocrystals; Ag nanoparticles; ZIF-8 catalysis; 4-nitrophenol reduction

\section{Introduction}

Functional nanocomposites represent an important class of nanomaterials and have attracted increased research interest due to their superior properties compared with individual components [1]. As an important member of nanocomposites family, the magnetic nanocatalyst is very attractive because it provides a convenient way to remove and recycle the nanocatalyst from the reaction system [2]. $\mathrm{MFe}_{2} \mathrm{O}_{4}$ ferrite, which is a well-known ternary spinel structure with $\mathrm{M}^{2+}$ ions on $\mathrm{B}$ sites and $\mathrm{Fe}^{3+}$ ions located equally among A and B sites, has high thermal, mechanical, and chemical stability and versatile catalytic, electric, and magnetic properties, and it exhibits promise for applications in electronics, lithium ion batteries, sensors, catalysis, and diagnostic medicine [3,4]. $\mathrm{CuFe}_{2} \mathrm{O}_{4}$ possesses high electronic conductivity, high thermal stability, and high activity for the hydrogenation of 4-nitrophenol (4-NP), which is a toxic and inhibitory in nature, to yield industrially important anilines like 4-aminophenol [5-7]. 
More often, hybrid composites are fabricated through an in-situ method, where the templates have a high affinity towards metal ions that allows for the synthesis of metallic nanoparticles [8]. Cellulose nanocrystals (CNC) are derived from abundant cellulosic resources such as plants and microbial cellulose via sulfuric acid hydrolysis $[9,10]$. CNC have well-defined size and morphology, high specific surface area, high aspect ratio, high crystalline order, chirality, high mechanical strength, and controllable surface chemistry [11], which are appealing in a plethora of materials to catalytic applications. As reported in our previous research [12], the $\mathrm{CuFe}_{2} \mathrm{O}_{4} / \mathrm{CNC}$ nanocomposites show good dispersity and it has been suggested that the nanocomposites do catalyze 4-NP reduction.

To further improve the catalytic activity, various core/shell-structured magnetic nanocatalysts have been applied in nanocatalysis [13-16]. The as-obtained $\mathrm{CuFe}_{2} \mathrm{O}_{4}$ based core-shell nanocomposites showed excellent catalytic activity, magnetic separation, and magnetic carrying in nanocatalysis. Recently, the Ag modified magnetic composites have gained increasing attention because of the high catalytic activity of the Ag component, the good magnetic responsiveness of the magnetic core, and the relatively facile fabrication process [17-19]. Various noble metals, including $\mathrm{Au}, \mathrm{Pd}$, and $\mathrm{Pt}$ have been widely employed as catalysts for the reduction of 4-NP to 4-AP by $\mathrm{NaBH}_{4}$ in aqueous media [20-23]. Moreover, $\mathrm{Ag}$ is more suitable for large-scale application than other noble metals $(\mathrm{Au}, \mathrm{Pd}$, and $\mathrm{Pt}$ ) because of its low price [24]. Dopamine can self-polymerize under specific conditions to form a polydopamine (PDA) complex which has the ability of adhering onto the surface of various materials due to the strong stickiness [25-27] and the abundant catechol groups on the PDA complex can reduce metal into metal directly [28,29]. In this regard, $\mathrm{Ag}$ catalysts supported on ferrite, $\mathrm{Fe}_{3} \mathrm{O}_{4}, \mathrm{Fe}_{3} \mathrm{O}_{4} @ P D A$, etc., have been used as magnetic catalysts for catalytic reduction. Recently, Wu et, al. fabricated $\mathrm{Fe}_{3} \mathrm{O}_{4} @$ PDA-Ag nanocomposites and used them as an efficient catalyst for methylene blue reduction owing to Ag nanoparticles (NPs) [27]. CNC, crystalline cellulose nanofibers, and their derivatives, were good supports for the preparation of supported Ag NPs [11,30]. Moreover, CNC have eminent colloidal stability due to the interelectrostatic repulsions of the negatively charged sulfate ester groups on CNC [31,32]. These sulfate groups have been proven to favor stabilization and nucleation of Ag NPs in a recent research [11]. However, the introduction of CNC in magnetic catalyst is uncommon. The catalyst with CNC combines the advantages of magnetic and catalytic.

The ZIF-8 framework $\left(\mathrm{Zn}(\mathrm{MeIM})_{2}, \mathrm{MeIM}=2\right.$-methylimidazole) holds an intersecting 3D structure, high thermal and chemical stabilities, and large pore size and surface area, which are desirable for depositing metal NPs [33]; it can also rapid adsorb chemical pollutants from aqueous solutions. ZIF-8 has uniform but tunable cavities, tailorable chemistry, and is suited to stabilizing noble metal-NPs without blocking their surfaces, making them very attractive in catalysis [7]. Furthermore, proper design and construction of ZIF-8 nanocomposites by integrating functional materials (such as metal NPs, metal oxides, and polymers) are expected to present synergistically boosted catalytic activity, enhanced stability, and prolonged lifetimes [34,35] which would open new opportunity for fabricating highly efficient hierarchical core-shell catalysts [36].

Herein, we report the synthesis of cellulose nanocrystals (CNC) supported magnetic $\mathrm{CuFe}_{2} \mathrm{O}_{4} @ \mathrm{Ag} @ \mathrm{ZIF}-8$ nanocomposites. It consists of a paramagnetic $\mathrm{CuFe}_{2} \mathrm{O}_{4} / \mathrm{CNC} @ \mathrm{Ag}$ core and a porous ZIF-8 shell via a facile method. CNC was used as a template and dispersant for the incorporate with $\mathrm{CuFe}_{2} \mathrm{O}_{4} \mathrm{NPs}$ and an absorbent via $\pi-\pi$ stacking interactions of 4-NP. In addition, we used PDA as an intermediate, which can not only protect the $\mathrm{CuFe}_{2} \mathrm{O}_{4} \mathrm{NPs}$ from corrosion in harsh environments and immobilize Ag NPs, but also induce the growth of ZIF-8 on the surface of the $\mathrm{CuFe}_{2} \mathrm{O}_{4} / \mathrm{CNC} @ \mathrm{Ag}$. The as-synthesized $\mathrm{CuFe}_{2} \mathrm{O}_{4} / \mathrm{CNC@Ag@ZIF-8} \mathrm{nanocomposites} \mathrm{showed} \mathrm{outstanding} \mathrm{catalytic} \mathrm{activity}$ and reusability for the reduction of 4-NP. To our best knowledge, this is the first report on the integration of ZIF-8 with $\mathrm{CuFe}_{2} \mathrm{O}_{4} / \mathrm{CNC} @ \mathrm{Ag}$ into one nanostructure to significantly improve not only the intrinsic catalytic performances of Ag active species, but also the recyclability of catalysts. 


\section{Results and Discussion}

\subsection{Characterization of $\mathrm{CuFe}{ }_{2} \mathrm{O}_{4} / \mathrm{CNC@Ag}$ and $\mathrm{CuFe}{ }_{2} \mathrm{O}_{4} / \mathrm{CNC} @ A g @ Z I F-8$ Nanocomposites}

The general schemes for the synthesis of the $\mathrm{CuFe}_{2} \mathrm{O}_{4} / \mathrm{CNC} @ \mathrm{Ag} @ Z I F-8$ nanocomposites are illustrated in Scheme 1, which mainly involved three steps: (1) Firstly, one-pot solvothermal synthesis of cellulose nanocrystals supports $\mathrm{CuFe}_{2} \mathrm{O}_{4}$ NPs, and the network of cellulose nanocrystals can significantly enhance the dispersion stability. (2) Secondly, as a result of its unique self-adhesive and reductive nature, the PDA layer shows sufficient reductive capacity to reduce $\mathrm{Ag}^{+}$ions without the need for additional reducing agent [37]. By then, Ag NPs with sizes ranging from 20 to $30 \mathrm{~nm}$ in sphere shapes can be uniformly formed along the $\mathrm{CuFe}_{2} \mathrm{O}_{4}$ and $\mathrm{CNC}$ networks surface with the aid of adhesive and reductive PDA layer under alkaline conditions. (3) Thirdly, using $\mathrm{Zn}\left(\mathrm{NO}_{3}\right)_{2} \cdot 2 \mathrm{H}_{2} \mathrm{O}$ and 2-methylimidazole as precursors, the ZIF-8 shell with controllable thickness was coated on the surface of $\mathrm{CuFe}_{2} \mathrm{O}_{4} / \mathrm{CNC@Ag}$. The composite is prepared by layer-by-layer.

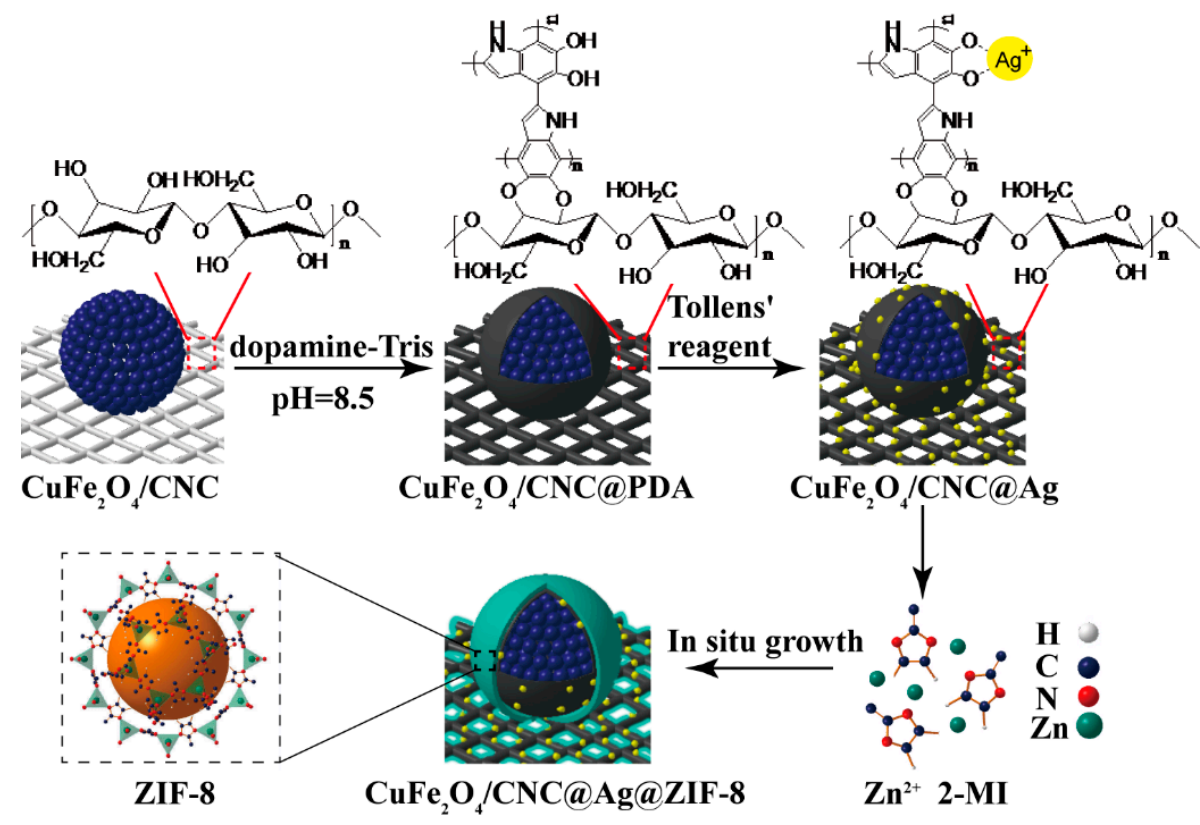

Scheme 1. Schematic representation of the synthesis of magnetic $\mathrm{CuFe}_{2} \mathrm{O}_{4} / \mathrm{CNC@Ag@ZIF-8} \mathrm{nanocomposites.}$

Transmission electron microscopy (TEM) measurements revealed that the $\mathrm{CuFe}_{2} \mathrm{O}_{4} \mathrm{NPs}_{\text {had good }}$ monodispersity in the CNC network with a mean size of about $250 \mathrm{~nm}$ (Figure 1A). The pristine CNC) had a length of ca. 200-250 nm and a width of 15-20 nm, which is typical for CNC [38]. $\mathrm{CuFe}_{2} \mathrm{O}_{4}$ NPs shown in Figure 1A were well dispersed in the presence of CNC substrate, which supported the conclusion that CNC can act as a good dispersant/support of nanoparticles, preventing the NPs' aggregation due to the excellent properties of CNC [38]. Figure 1B showed that uniform and dense Ag NPs, with an average size of $25 \mathrm{~nm}$ successfully distributed on the PDA surface, and no free Ag NPs were observed. The CNC networks became dark after coating PDA. The thin PDA shell layers formed around the $\mathrm{CuFe}_{2} \mathrm{O}_{4} / \mathrm{CNC}$ cores showed an average size of about $20 \mathrm{~nm}$ (Figure 1C), displaying a distant core-shell structure. Figure $1 \mathrm{E}$ confirmed that the boundary between the ZIF-8 and PDA was obscure, which was attributed to the slight mass difference of the two components. Compared with $\mathrm{CuFe}_{2} \mathrm{O}_{4} / \mathrm{CNC@Ag}, \mathrm{CuFe}_{2} \mathrm{O}_{4} / \mathrm{CNC@Ag@ZIF-8} \mathrm{nanocomposites} \mathrm{had} \mathrm{a} \mathrm{distinct} \mathrm{core-shell} \mathrm{structure;}$ the thickness of ZIF-8 shell surrounding the $\mathrm{CuFe}_{2} \mathrm{O}_{4} / \mathrm{CNC@Ag}$ was approximately $45 \mathrm{~nm}$, and there was a controllable particle diameter ranging from 350 to $400 \mathrm{~nm}$. Figure $1 \mathrm{~F}$ displays a lattice resolved HRTEM image of $\mathrm{CuFe}_{2} \mathrm{O}_{4}$ nanocrystal on $\mathrm{CNC}$. The distinct lattice fringes with interplanar spacings 
of 0.25 and $0.235 \mathrm{~nm}$ match well the (311) crystal plane of the $\mathrm{CuFe}_{2} \mathrm{O}_{4}$ cubic spinel structure [39] and the (111) plane of Ag, respectively [40].

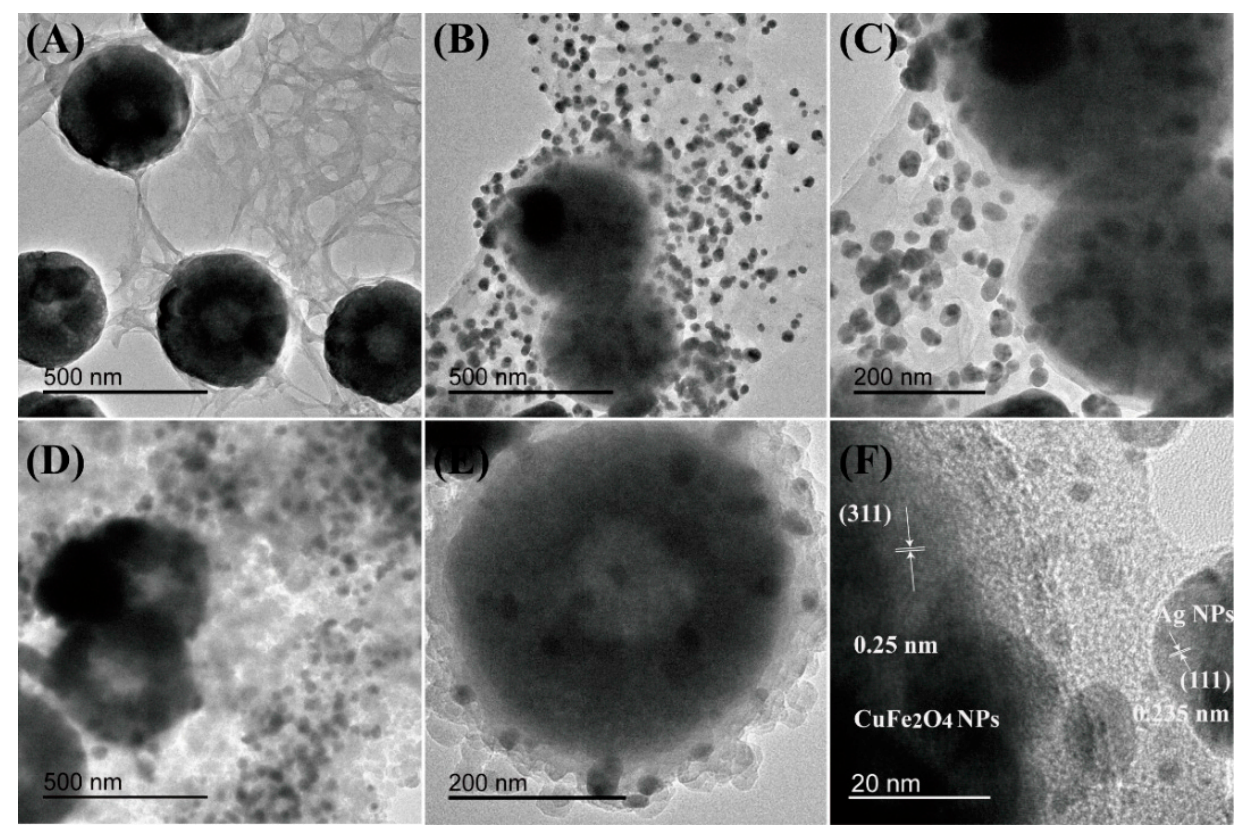

Figure 1. TEM images of the (A) $\mathrm{CuFe}_{2} \mathrm{O}_{4} / \mathrm{CNC}$ nanocomposites; (B,C) $\mathrm{CuFe}_{2} \mathrm{O}_{4} / \mathrm{CNC} @ \mathrm{Ag}$ nanocomposites; (D,E) $\mathrm{CuFe}_{2} \mathrm{O}_{4} / \mathrm{CNC} @ \mathrm{Ag} @ Z \mathrm{ZIF}-8$ nanocomposites; (F) HRTEM image of CuFe2O4 nanoparticles (NPs) and Ag NPs.

HAADF-STEM also confirmed the typical nanostructure of the nanocomposites (Figure 2A). The EDX mapping of the $\mathrm{Cu}$ and Fe elements revealed that $\mathrm{CuFe}_{2} \mathrm{O}_{4}$ was mainly located within the nanocomposites (Figure 2B). The diameters of the $\mathrm{N}$ element map were larger than that of the $\mathrm{Cu}$ and $\mathrm{Fe}$, which further supported the fact that the PDA were successfully coated. The Ag element was distributed around the $\mathrm{CuFe}_{2} \mathrm{O}_{4}$ because the density in the center was very low. In addition, the corresponding EDX spectra supported the conclusion that Ag NPs were embedded in the CNC substrate [38], forming the $\mathrm{CuFe}_{2} \mathrm{O}_{4} / \mathrm{CNC@Ag@ZIF-8} \mathrm{nanocomposites.} \mathrm{The} \mathrm{diameters} \mathrm{of} \mathrm{the} \mathrm{Zn}$ element map were larger than that of the $\mathrm{Ag}$, which further supported the fact that the Ag NPs were protected by ZIF-8. The Ag element was distributed on C element, which confirmed that Ag NPs were located on PDA shell (Figure 2C-I). On the basis of the TEM and EDX mapping, it could be concluded that the $\mathrm{CuFe}_{2} \mathrm{O}_{4} / \mathrm{CNC@Ag@ZIF-8} \mathrm{nanocomposites} \mathrm{with} \mathrm{core-shell} \mathrm{structure} \mathrm{had} \mathrm{been} \mathrm{successfully}$ achieved in Figure 2J. 

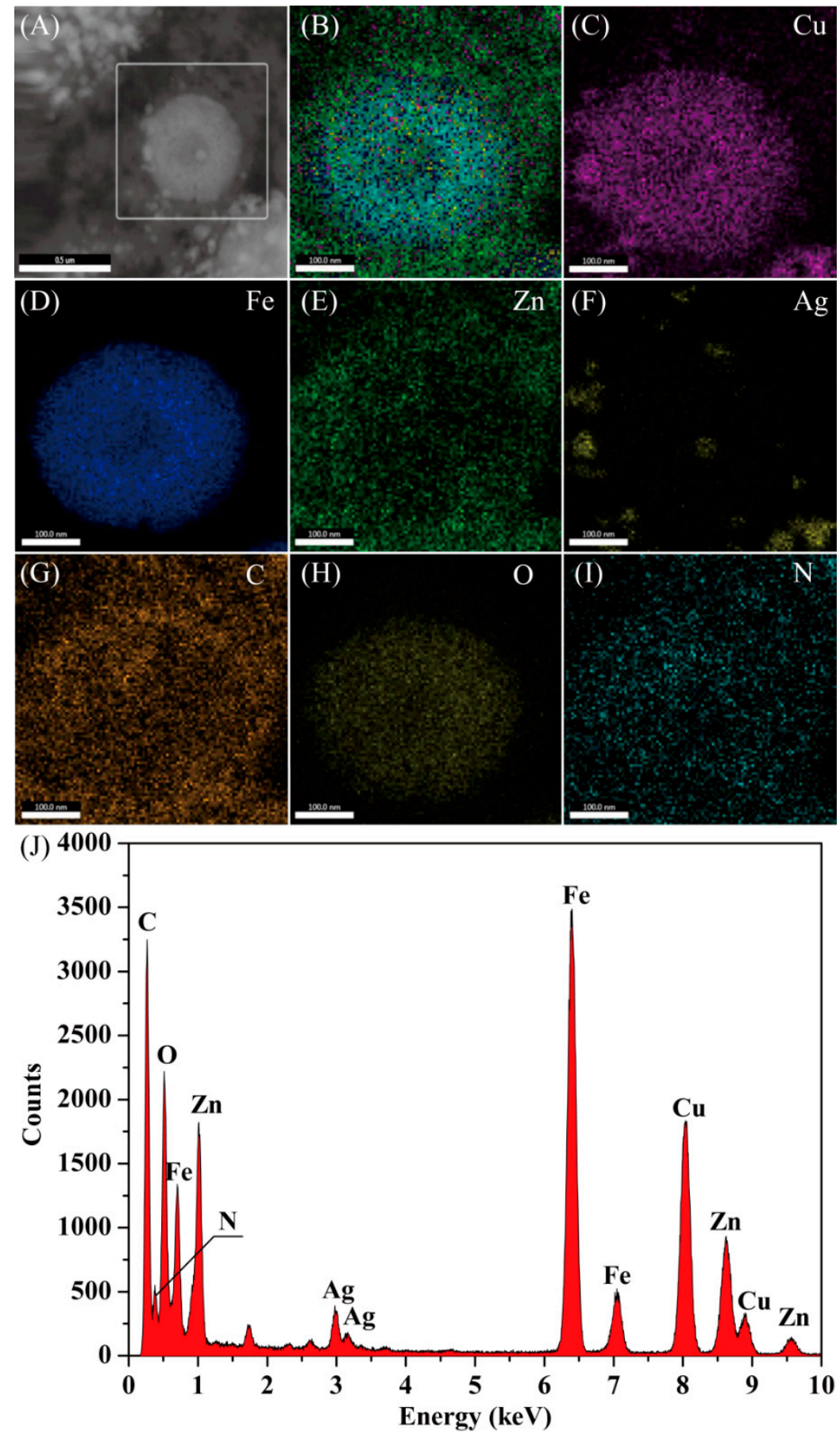

Figure 2. Representative high-angle annular dark field scanning TEM (HAADF-STEM) images and energy-dispersive X-ray (EDX) elemental mapping of $\mathrm{Cu}, \mathrm{Fe}, \mathrm{Zn}, \mathrm{Ag}, \mathrm{C}, \mathrm{O}$, and $\mathrm{N}(\mathrm{A}-\mathrm{I})$ and the EDX spectrum (J) of the $\mathrm{CuFe}_{2} \mathrm{O}_{4} / \mathrm{CNC@Ag@ZIF-8} \mathrm{nanocomposites.}$

Figure 3A presents the FTIR spectra of (a) $\mathrm{CuFe}_{2} \mathrm{O}_{4} / \mathrm{CNC}$, (b) $\mathrm{CuFe}_{2} \mathrm{O}_{4} / \mathrm{CNC} @ \mathrm{PDA}$, (c) $\mathrm{CuFe}_{2} \mathrm{O}_{4} / \mathrm{CNC} @ \mathrm{Ag}$, and (d) $\mathrm{CuFe}_{2} \mathrm{O}_{4} / \mathrm{CNC} @ \mathrm{Ag} @ \mathrm{ZIF}-8$. In line (a), the adsorption peaks at $430 \mathrm{~cm}^{-1}, 580 \mathrm{~cm}^{-1}$, and $3425 \mathrm{~cm}^{-1}$ correspond to the $\mathrm{Fe}-\mathrm{O}, \mathrm{Cu}-\mathrm{O}$, and $\mathrm{O}-\mathrm{H}$ stretching vibrations, respectively [41,42]. The band at $1645 \mathrm{~cm}^{-1}$ was due to the $\mathrm{O}-\mathrm{H}$ bending vibration in CNC [43]. The absorbance bands at $2893 \mathrm{~cm}^{-1}, 1400 \mathrm{~cm}^{-1}$ and $1060 \mathrm{~cm}^{-1}$ were assigned to the $\mathrm{C}-\mathrm{H}$ stretching vibration, the $\mathrm{C}-\mathrm{H}$ deformation vibration and the $\mathrm{C}-\mathrm{O}-\mathrm{C}$ stretching of pyranose, respectively $[15,44]$, which indicated that the $\mathrm{CuFe}_{2} \mathrm{O}_{4} \mathrm{NPs}$ were successfully immobilized on the CNC. In line (b), besides 
the characteristic adsorption peaks of line (a), the adsorption peaks at $1513 \mathrm{~cm}^{-1}$ are related to the $C=C$ stretching vibrations of aromatic ring [29]; the broad peak at $3390 \mathrm{~cm}^{-1}$ is attributed to the $\mathrm{O}-\mathrm{H}$ and $\mathrm{N}-\mathrm{H}$ stretching vibrations [42]; the peak appearing at $1294 \mathrm{~cm}^{-1}$ can be assigned to the $\mathrm{C}-\mathrm{OH}$ stretching vibration of phenol compounds [43]; all the peaks above demonstrate that the $\mathrm{CuFe}_{2} \mathrm{O}_{4} / \mathrm{CNC@PDA}$ nanocomposites were successfully prepared. After immobilizing Ag on the $\mathrm{CuFe}_{2} \mathrm{O}_{4} / \mathrm{CNC} @ \mathrm{PDA}$ (line c), the intensity of the peak at $1294 \mathrm{~cm}^{-1}$ become weaker owing to the interaction between Ag NPs and PDA. The band at $421 \mathrm{~cm}^{-1}$ (shown in line (d)) was attributed to the $\mathrm{Zn}-\mathrm{N}$ stretch mode [44]. The bands in the spectral region of $500-1350 \mathrm{~cm}^{-1}$ and $1350-1500 \mathrm{~cm}^{-1}$ were assigned as the plane bending and stretching of imidazole ring, respectively [44]. The bands of $2500-3500 \mathrm{~cm}^{-1}$ could be ascribed to stretching vibrations of $-\mathrm{CH}_{3},-\mathrm{NH}-$ and $-\mathrm{OH}(\mathrm{Zn}-\mathrm{OH})$ within the internal structure of $\mathrm{ZIF}-8$ [45].
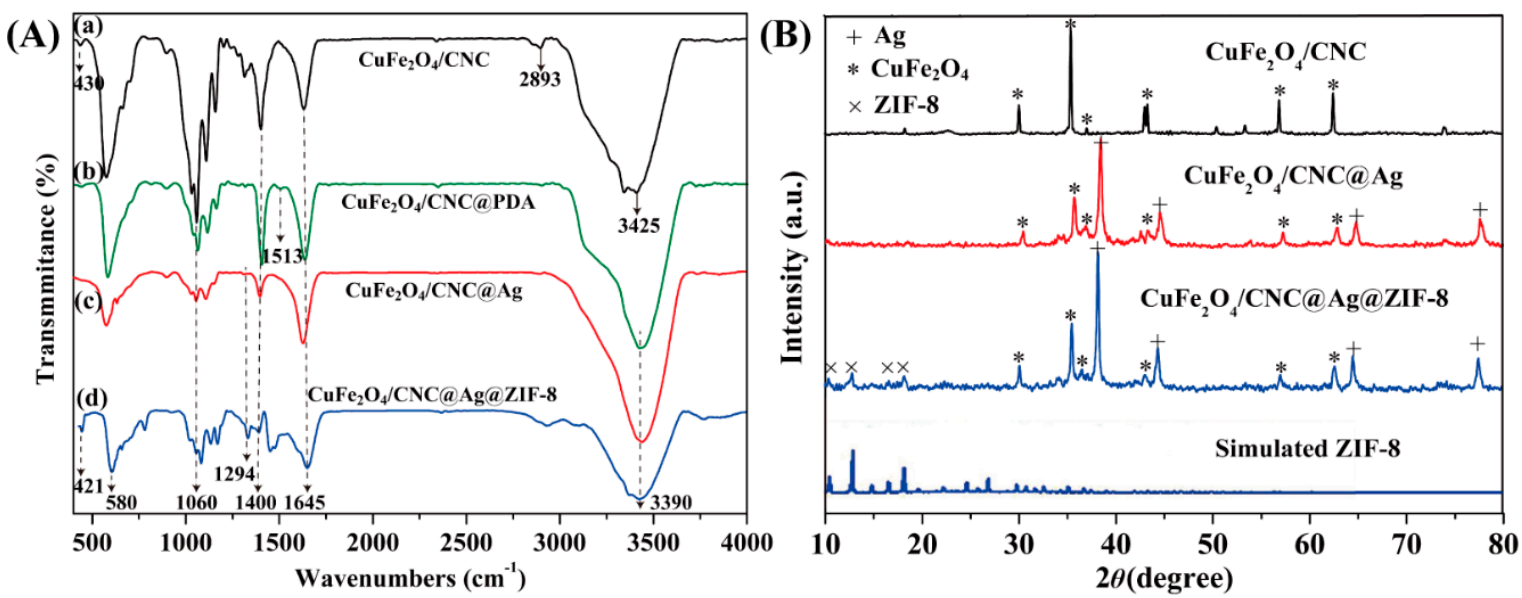

Figure 3. (A) Fourier transform infrared (FTIR) spectra of (a) $\mathrm{CuFe}_{2} \mathrm{O}_{4} / \mathrm{CNC}$, (b) $\mathrm{CuFe}_{2} \mathrm{O}_{4} / \mathrm{CNC} @ \mathrm{PDA}$, (c) $\mathrm{CuFe}_{2} \mathrm{O}_{4} / \mathrm{CNC} @ \mathrm{Ag}$, and (d) $\mathrm{CuFe}_{2} \mathrm{O}_{4} / \mathrm{CNC} @ \mathrm{Ag} @ Z I F-8$ nanocomposites; (B)XRD diffraction patterns of $\mathrm{CuFe}_{2} \mathrm{O}_{4} / \mathrm{CNC}, \mathrm{CuFe}_{2} \mathrm{O}_{4} / \mathrm{CNC} @ \mathrm{Ag}, \mathrm{CuFe}_{2} \mathrm{O}_{4} / \mathrm{CNC} @ \mathrm{Ag} @ \mathrm{ZIF}-8$ nanocomposites, and simulated XRD pattern for ZIF-8.

To probe the presence of Ag NPs and ZIF- 8 attached onto the $\mathrm{CuFe}_{2} \mathrm{O}_{4} / \mathrm{CNC}$, XRD patterns were carried out during the experiments (Figure 3B). It was observed that for $\mathrm{CuFe}_{2} \mathrm{O}_{4} / \mathrm{CNC}$, two peaks at $2 \theta=11.27$ and $21.94^{\circ}$ corresponded to the typical (101) and (020) lattice planes of cellulose [37], and the diffraction peaks located at $18.5^{\circ}, 30.2^{\circ}, 35.5^{\circ}, 37.0^{\circ}, 43.4^{\circ}, 57.3^{\circ}$, and $62.6^{\circ}$ corresponded to the (111), (220), (311), (222), (400), (422), (511), and (440) lattice planes, which matched well with those from the JCPDS card number 25-0283 for $\mathrm{CuFe}_{2} \mathrm{O}_{4}$ [46]. But for $\mathrm{CuFe}_{2} \mathrm{O}_{4} / \mathrm{CNC} @ \mathrm{Ag}$ and $\mathrm{CuFe}_{2} \mathrm{O}_{4} / \mathrm{CNC} @ \mathrm{Ag} @ Z I F-8$ nanocomposites, the XRD diffraction peaks derived from cellulose showed a slight decrease, and meanwhile, four diffraction peaks at $2 \theta=39.86^{\circ}, 44.23^{\circ}, 64.47^{\circ}$, and $77.33^{\circ}$ appeared, assigned respectively, to (111), (200), (220), and (311) lattice planes, and supported the face-centered cubic (fcc) structure of Ag NPs [47,48], an indication of successful formation of Ag NPs via efficient in situ reduction by PDA layer. The XRD pattern of $\mathrm{CuFe}_{2} \mathrm{O}_{4} / \mathrm{CNC} @ \mathrm{Ag} @ Z I F-8$ nanocomposites indicated that the products were well crystallized and had high crystallinity even after coating ZIF-8 shell. Moreover, the diffraction peaks at $2 \theta=10.4^{\circ}, 12.8^{\circ}, 14.7^{\circ}, 16.5^{\circ}$, and $18.1^{\circ}$ correspond to the (002), (112), (022), (013), and (222) lattice planes of ZIF-8 in the CuFe $\mathrm{O}_{4} / \mathrm{CNC} @$ Ag@ZIF-8 nanocomposites, respectively, suggesting that the ZIF-8 materials synthesized using current protocol are highly crystalline.

The porosity of evacuated composites was investigated by nitrogen-sorption measurements. As presented in Figure 4A, the $\mathrm{CuFe}_{2} \mathrm{O}_{4} / \mathrm{CNC} @ \mathrm{Ag}$ and $\mathrm{CuFe}_{2} \mathrm{O}_{4} / \mathrm{CNC} @ \mathrm{Ag} @ \mathrm{ZIF}-8$ nanocomposites exhibited a typical type $\mathrm{V}$ isotherm, validating a mesoporous characteristic [7]. The pore-size distribution (Figure B) revealed that the $\mathrm{CuFe}_{2} \mathrm{O}_{4} / \mathrm{CNC} @ \mathrm{Ag} @ \mathrm{ZIF}-8$ nanocomposites contained an average pore size of $4.0 \mathrm{~nm}$ which is lower than that of $\mathrm{CuFe}_{2} \mathrm{O}_{4} / \mathrm{CNC} @ \mathrm{Ag}(8.9 \mathrm{~nm})$ in favor of the prevention of $\mathrm{Ag}$ active sites leaching. In addition, the specific surface area and the pore volume of 
the $\mathrm{CuFe}_{2} \mathrm{O}_{4} / \mathrm{CNC} @ \mathrm{Ag} @ Z \mathrm{ZIF}-8$ nanocomposites were calculated to be $160.17 \mathrm{~m}^{2} / \mathrm{g}$, which is four times higher than that of $\mathrm{CuFe}_{2} \mathrm{O}_{4} / \mathrm{CNC@Ag}\left(38.68 \mathrm{~m}^{2} / \mathrm{g}\right)$. The high external surface area and mesoporous structure endowed the $\mathrm{CuFe}_{2} \mathrm{O}_{4} / \mathrm{CNC} @ \mathrm{Ag} @ \mathrm{ZIF}-8$ nanocomposites with high adsorption capacity and fast diffusion of reactants [17].
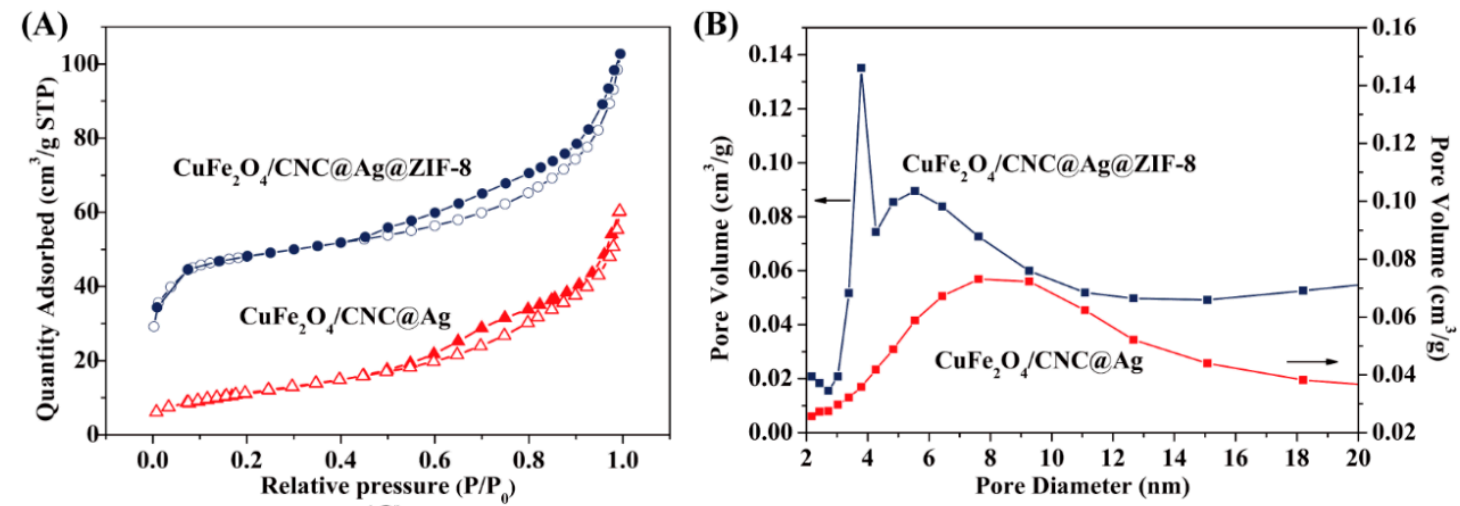

(C)

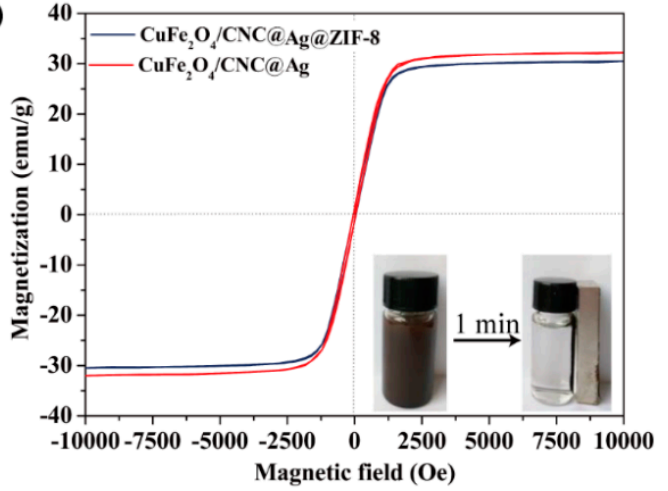

Figure 4. (A) $\mathrm{N}_{2}$ adsorption-desorption isotherms; (B) the pore-distribution curves; (C) the magnetic hysteresis curves of the $\mathrm{CuFe}_{2} \mathrm{O}_{4} / \mathrm{CNC} @ \mathrm{Ag} @ \mathrm{ZIF}-8$ and $\mathrm{CuFe}_{2} \mathrm{O}_{4} / \mathrm{CNC} @ \mathrm{Ag}$ nanocomposites (the inset shows the magnetic separation behavior of the $\mathrm{CuFe}_{2} \mathrm{O}_{4} / \mathrm{CNC@Ag@ZIF-8} \mathrm{nanocomposites} \mathrm{in} \mathrm{the}$ aqueous solution).

The saturation magnetization $\left(M_{\mathrm{S}}\right)$ is a physical quantity that can reflect the magnetism of a substance. Both $\mathrm{CuFe}_{2} \mathrm{O}_{4} / \mathrm{CNC} @ \mathrm{Ag}$ and $\mathrm{CuFe}_{2} \mathrm{O}_{4} / \mathrm{CNC} @ \mathrm{Ag} @ Z I F-8$ nanocomposites were paramagnetic with little hysteresis and remanence, processing $M_{\mathrm{S}}$ values of 31.2 and $30.1 \mathrm{emu} / \mathrm{g}$, respectively. Due to the coating of antimagnetic ZIF-8 shell, the saturation magnetization $\left(M_{\mathrm{s}}\right)$ decreased a little. As presented in Figure 4B, the $\mathrm{CuFe}_{2} \mathrm{O}_{4} / \mathrm{CNC} @ \mathrm{Ag} @ \mathrm{ZIF}-8$ nanocomposites were well dispersed in water and presented a black suspension. However, rapid aggregation $(\approx 1 \mathrm{~min})$ of the $\mathrm{CuFe}_{2} \mathrm{O}_{4} / \mathrm{CNC} @ \mathrm{Ag} @ Z \mathrm{ZIF}-8$ nanocomposites from the homogeneous suspension was obtained with the help of external magnet, and thus the dispersed solution became clear.

\subsection{Catalytic Reduction of 4-Nitrophenol}

Ag NPs have been generally used as excellent catalysts with high catalytic activity and selectivity for catalytic reduction or degradation of organic pollution in aqueous solution [38,39,46,49]. Many reports are available on the application of metal and metal oxides nanocatalysts for the reduction of nitrophenols in the presence of $\mathrm{NaBH}_{4}$ [50]. Herein, the catalytic reduction of 4-NP by $\mathrm{NaBH}_{4}$ was used as a model reaction to investigate the catalytic performances of $\mathrm{CuFe}_{2} \mathrm{O}_{4} / \mathrm{CNC}, \mathrm{CuFe}_{2} \mathrm{O}_{4} / \mathrm{CNC} @ \mathrm{Ag}$, and $\mathrm{CuFe}_{2} \mathrm{O}_{4} / \mathrm{CNC@Ag@ZIF-8} \mathrm{nanocomposites.} \mathrm{Although} \mathrm{the} \mathrm{aqueous} \mathrm{solution} \mathrm{of} \mathrm{4-nitrophenol}$ undergoes a rapid color change (with a UV-Vis absorption peak shift from 319 to $400 \mathrm{~nm}$ ) after adding $\mathrm{NaBH}_{4}$ due to the formation of 4-nitrophenolate ions, the reduction reaction does not proceed substantially in the absence of suitable catalysts (such as $\mathrm{Au}, \mathrm{Ag}$, Pd, and Pt NPs). 
Figure 5A suggested the catalytic reaction of $\mathrm{CuFe}_{2} \mathrm{O}_{4} / \mathrm{CNC} @ \mathrm{Ag}$ nanocomposites could be completed within $11 \mathrm{~min}$. As shown in Figure 5B, the adsorption peak at $400 \mathrm{~nm}$ was observed to decrease in intensity rapidly and disappear eventually after $6 \mathrm{~min}$, suggesting that the $\mathrm{CuFe}_{2} \mathrm{O}_{4} / \mathrm{CNC} @ \mathrm{Ag} @ \mathrm{ZIF}-8$ nanocomposites do catalyze 4-NP reduction. Since the ZIF-8 itself, in the control experiment, exhibited no propensity to catalyze the reduction reaction, the above result indicates that the 4-nitrophenol molecules can diffuse quickly through the channels of ZIF-8 matrix and react on the surfaces of the active $\mathrm{CuFe}_{2} \mathrm{O}_{4} @ \mathrm{Ag}$ NPs. In addition, the appearance of the new peak at $\approx 300 \mathrm{~nm}$ in the UV-Vis spectra suggested that the $\mathrm{CuFe}_{2} \mathrm{O}_{4} / \mathrm{CNC} @ \mathrm{Ag} @ Z \mathrm{ZIF}-8$ nanocomposites catalyze the reduction of 4-NP to give 4-aminophenol as the sole product.
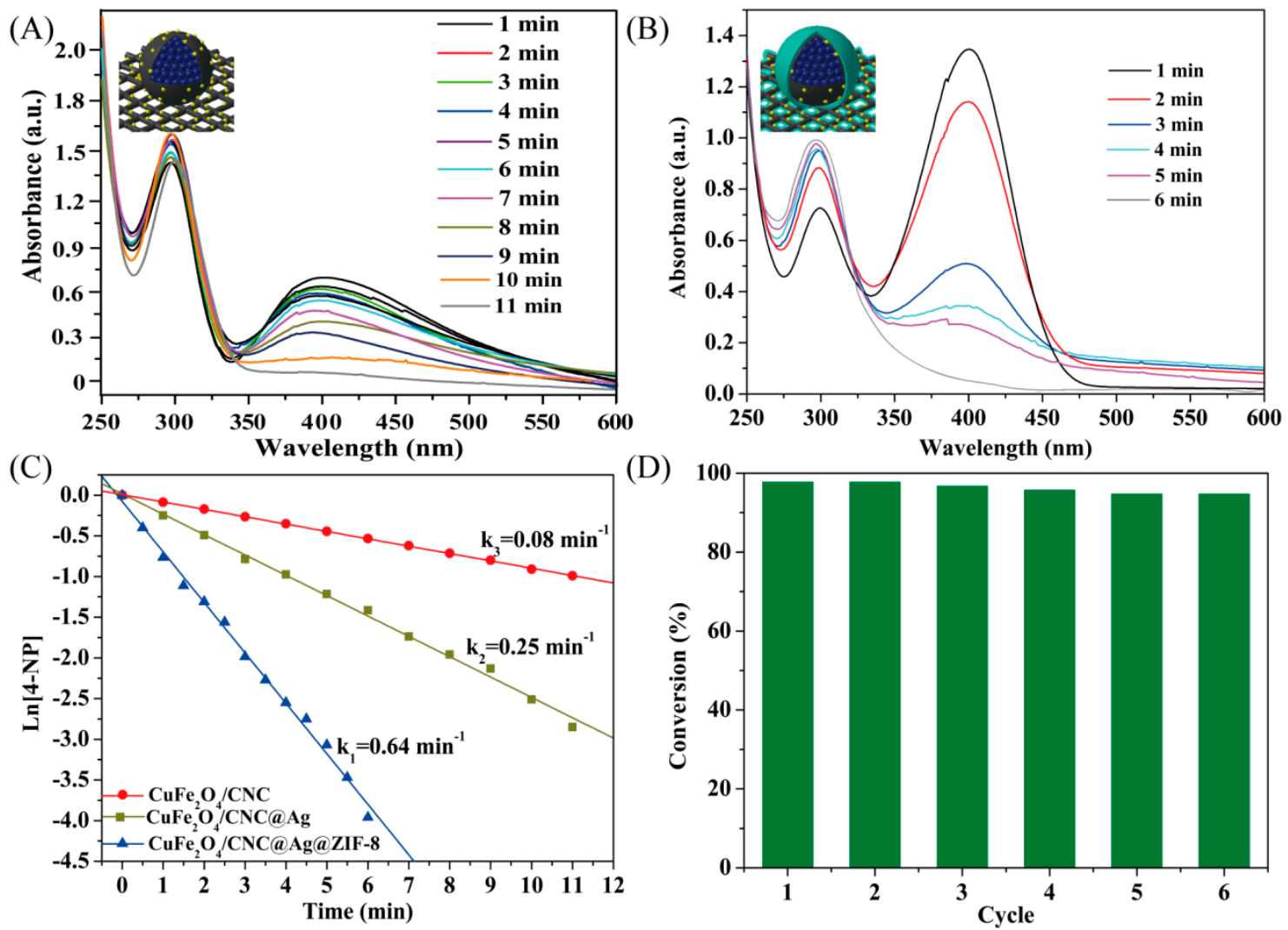

Figure 5. Typical time-dependent evolution of UV-Vis spectra showing the catalytic reduction of 4-NP to 4-AP by (A) $\mathrm{CuFe}_{2} \mathrm{O}_{4} / \mathrm{CNC@Ag;} \mathrm{(B)} \mathrm{CuFe}_{2} \mathrm{O}_{4} / \mathrm{CNC} @ \mathrm{Ag} @ Z I F-8$ nanocomposites; (C) plot of ln [4-NP] versus reaction time for the reduction of 4-NP using $3 \mathrm{mg} \mathrm{CuFe} \mathrm{O}_{4} / \mathrm{CNC}, \mathrm{CuFe}_{2} \mathrm{O}_{4} / \mathrm{CNC@Ag}$, and $\mathrm{CuFe}_{2} \mathrm{O}_{4} / \mathrm{CNC} @ \mathrm{Ag} @ \mathrm{ZIF}-8$ nanocomposites; (D) conversion of 4-NP during six cycles of reaction by the $\mathrm{CuFe}_{2} \mathrm{O}_{4} / \mathrm{CNC@Ag@ZIF-8} \mathrm{nanocomposites.}$

To elucidate the reaction mechanism, the concentration of $\mathrm{NaBH}_{4}$ could be considered as constant throughout the reaction since it was in great excess $(0.1 \mathrm{M})$. Therefore, pseudo-first-order kinetics with regard to the catalytic reduction of $4-\mathrm{NP}$, described as $\ln \left(C_{t} / C_{0}\right)=-k t$, can be applied, where $C_{\mathrm{t}}$ is the concentration of $4-\mathrm{NP}$ at time $t, C_{0}$ is the initial concentration of $4-\mathrm{NP}$, and $k$ is the rate constant $\{51\}$. Figure $5 \mathrm{C}$ shows the linear relationship of $\ln \left(C_{t} / C_{0}\right)$ as a function of reaction time $t$ for the 4-NP reduction catalyzed by three as-synthesized catalysts. The values of kinetic rate constant $k$ can be calculated from the rate equation $\ln \left(C_{t} / C_{0}\right)=-k t$. Impressively, the $\mathrm{CuFe}_{2} \mathrm{O}_{4} / \mathrm{CNC} @ \mathrm{Ag} @ Z \mathrm{ZIF}-8$ nanocomposites exhibit the highest activity with a rate constant estimated to be $0.64 \mathrm{~min}^{-1}, .5$ and eight times higher than that of $\mathrm{CuFe}_{2} \mathrm{O}_{4} / \mathrm{CNC} @ \mathrm{Ag}$ and that of $\mathrm{CuFe}_{2} \mathrm{O}_{4} / \mathrm{CNC}$, respectively, suggesting the higher catalytic efficiencies for Ag catalysts confined in ZIF-8 shell. This prominent catalytic activity can due to a porous ZIF-8 shell for stabilization of the encapsulated Ag NPs and rapid adsorption of chemical pollutants from aqueous solution. The catalytic active sites are both $\mathrm{CuFe}_{2} \mathrm{O}_{4}$ and $\mathrm{Ag}$ 
NPs in the core-shell structures, which modified the electronic structure, and then enhanced the catalytic activity.

The reusability of $\mathrm{CuFe}_{2} \mathrm{O}_{4} / \mathrm{CNC@Ag@ZIF-8} \mathrm{nanocomposites} \mathrm{as} \mathrm{the} \mathrm{catalyst} \mathrm{for} \mathrm{the} \mathrm{reduction} \mathrm{of}$ 4-NP was further confirmed by the observation of the similar conversion for the same reaction time (6 $\mathrm{min}$ ) for six consecutive cycles (the slightly decreased conversions in the later catalysis cycles were presumably caused by the loss of catalyst during the washing process between cycles (Figure 5D).

\subsection{Reaction Mechanism of $\mathrm{CuFe}_{2} \mathrm{O}_{4} / \mathrm{CNC@Ag@ZIF-8} \mathrm{Nanocomposites}$}

As illustrated in Scheme 2, the mechanism of catalytic reduction of 4-NP by the $\mathrm{CuFe}_{2} \mathrm{O}_{4} / \mathrm{CNC} @ \mathrm{Ag} @ \mathrm{ZIF}-8$ nanocomposites involved the traditional theory. In this work, the 4-NP can be adsorbed onto the mesoporous ZIF-8 shell via $\pi-\pi$ stacking interactions because 4 -NP is $\pi$-rich in nature [51]. Such chemical adsorption provides a high concentration of 4-NP near to the interface of the $\mathrm{CuFe}_{2} \mathrm{O}_{4} @ \mathrm{Ag}$ and $\mathrm{ZIF}-8$, leading to highly efficient contact between them. Simultaneously, $\mathrm{BH}_{4}^{-}$ was also adhered to the $\mathrm{CuFe}_{2} \mathrm{O}_{4} / \mathrm{CNC} @ \mathrm{Ag}$ surface and transferred electrons and hydride ions to the Ag NPs' surface. In addition, Zhou et al. claimed that when metal oxide closely contacted with metal, Fermi level alignment would lead to charge redistribution: electrons would escape from the metal and transfer into the semiconductor [52]. Liang et, al. used $\mathrm{Ag} / \mathrm{Fe}_{3} \mathrm{O}_{4} \mathrm{NPs}$ as the catalyst for the reduction of 4-NP [53]. They reported that the electrons tended to leave $\mathrm{Ag}$ to $\mathrm{Fe}_{3} \mathrm{O}_{4}$ and thus form a depleted region close to the $\mathrm{Ag} / \mathrm{Fe}_{3} \mathrm{O}_{4}$ interface. In our work, $\mathrm{CuFe}_{2} \mathrm{O}_{4}$ was known as a p-type semiconductor with low band gap, so part of the electrons and hydride ion that injected from $\mathrm{BH}_{4}^{-}$to $\mathrm{Ag} \mathrm{NPs} \mathrm{could}$ transfer to the neighboring $\mathrm{CuFe}_{2} \mathrm{O}_{4}$ surface (Scheme 2). The existence of the surplus electrons on $\mathrm{CuFe}_{2} \mathrm{O}_{4}$ provided large surface area and increased opportunities for reduction reaction, facilitating the capture of electrons by 4-NP molecules. Goyal et al. suggested that electron transfer between $\mathrm{Cu}^{+}-\mathrm{Cu}^{2+}$ and $\mathrm{Fe}^{2+}-\mathrm{Fe}^{3+}$ in the octahedral sites endowed $\mathrm{CuFe}_{2} \mathrm{O}_{4}$ with enhanced catalytic activity [54] (Scheme 2). Herein, when the electrons and hydride ions were transfered to the $\mathrm{CuFe}_{2} \mathrm{O}_{4}$ surface, both $\mathrm{Cu}^{2+}$ and $\mathrm{Fe}^{3+}$ ions present in the octahedral sites were exposed on the surfaces of particles. Due to that, there were transfers of electrons between $\mathrm{Cu}^{+}-\mathrm{Cu}^{2+}$ and $\mathrm{Fe}^{2+}-\mathrm{Fe}^{3+}$ ion pairs, which enhanced catalytic activity. Then the hydrogen atom transfers from $\mathrm{BH}_{4}^{-}$to the 4-NP, resulting in the formation of 4-AP. Finally, the products of 4-AP are desorbed from the surface of the catalysts to the solution through the channels of the ZIF-8 shell.

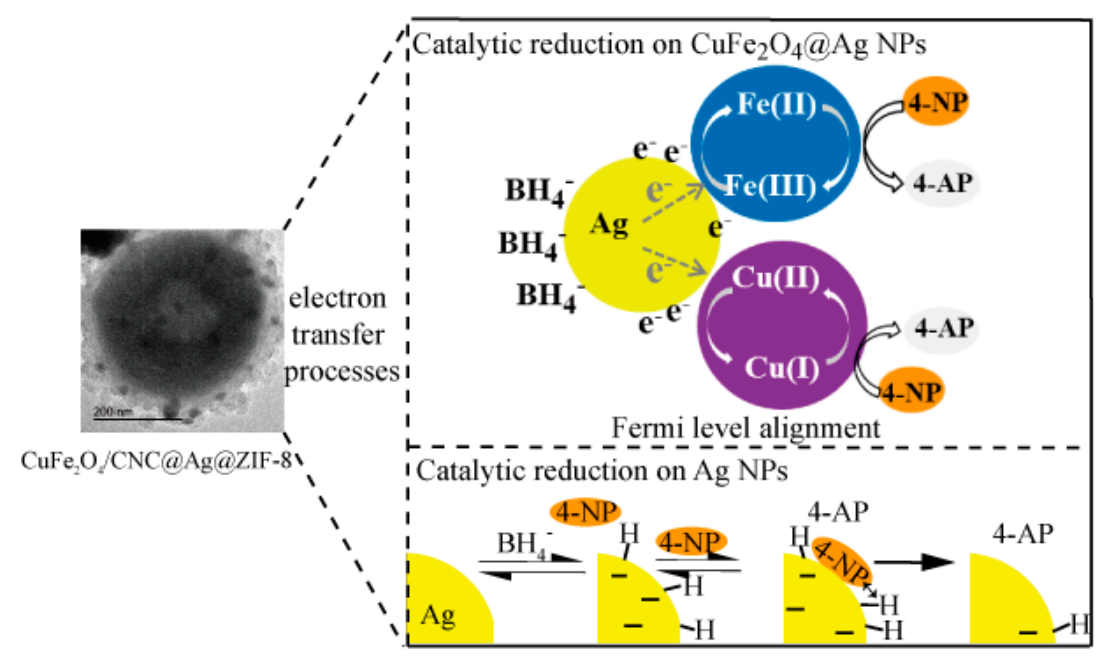

Scheme 2. The mechanism of the reduction of 4-nitrophenol (4-NP) to 4-aminophenol (4-AP) by $\mathrm{NaBH}_{4}$ in the $\mathrm{CuFe}_{2} \mathrm{O}_{4} / \mathrm{CNC@Ag@ZIF-8} \mathrm{nanocomposites.}$

It should be noted that the bleaching rate is considerably higher than the rates reported previously under the similar experimental conditions with Ag-based, $\mathrm{CuFe}_{2} \mathrm{O}_{4}$-based, and MOF-based catalysts. 
The $k$ values of different catalytic systems for the reduction of 4-NP were comparable to the values referenced in Table 1, and the results showed that the prepared catalyst possessed higher activity and lower activation energy.

Table 1. Comparison of $k$ of different catalytic systems for the reduction of 4-NP (298K).

\begin{tabular}{cccc}
\hline Entry & Nanocatalysts & $\left.\boldsymbol{k} \mathbf{( m i n}^{-\mathbf{1}}\right)$ & Reference \\
\hline 1 & $\mathrm{Ag} / \mathrm{C}$ & 0.33 & {$[55]$} \\
2 & $\mathrm{Fe}_{3} \mathrm{O}_{4} @ \mathrm{SiO}_{2} @ \mathrm{Ag}$ & 0.52 & {$[56]$} \\
3 & $\mathrm{Au} / \mathrm{TAPB}-\mathrm{DMTP}-\mathrm{COF}$ & 0.46 & {$[57]$} \\
4 & $\mathrm{Au} @ \mathrm{TpPa}-1$ & 0.25 & {$[53]$} \\
5 & $\mathrm{Ag} \mathrm{NPs@CMG}$ & 0.204 & {$[55]$} \\
6 & $\mathrm{CuFe} \mathrm{O}_{4} @ \mathrm{Ag} @ \mathrm{ZIF}-8$ & 0.64 & This work \\
\hline
\end{tabular}

\section{Materials and Methods}

\subsection{Chemicals}

All the reagents used were of analytical purity and were used without further purification. Polyethylene glycol-6000 (PEG-6000), polyvinylpyrrolidone (PVP-1300000), dopamine hydrochloride (DA. $\mathrm{HCl})$, and 2-methylimidazole $\left(\mathrm{C}_{4} \mathrm{H}_{6} \mathrm{~N}_{2}\right)$ were purchased from Shanghai Aladdin Industrial Co., Ltd. (Shanghai, China). Cupric chloride anhydrous $\left(\mathrm{CuCl}_{2}\right)$ and other reagents, such as ferric chloride hexahydrate $\left(\mathrm{FeCl}_{3} \cdot 6 \mathrm{H}_{2} \mathrm{O}\right)$, ammonium acetate $\left(\mathrm{NH}_{4} \mathrm{OAc}\right)$, ethylene glycol (EG), silver nitrate $\left(\mathrm{AgNO}_{3}\right)$, 4-nitrophenol(4-NP), sodium borohydride $\left(\mathrm{NaBH}_{4}\right)$, and zinc nitrate $\left(\mathrm{Zn}\left(\mathrm{NO}_{3}\right)_{2} \cdot 6 \mathrm{H}_{2} \mathrm{O}\right)$ were purchased from Sigma-Aldrich (Shanghai, China). Cellulose nanocrystals (CNCs) were purchased from Tianjin Haojia Cellulose Co., Ltd. (Tianjin, China).

\subsection{Measurements}

Sample morphologies with energy-dispersive X-ray spectroscopy (EDX) were characterized by transmission electron microscopy (TEM) on a TECNAI G2 TF20 (U.S.). FT-IR spectra of all samples in the wavenumber range $4000-400 \mathrm{~cm}^{-1}$ were obtained in $\mathrm{KBr}$ pressed pellets on a TENSOR model 27 FTIR spectrometer (Germany, Bruker). The powder X-ray diffraction spectra (XRD) were measured by X-ray diffraction (Germany, Bruker, D8Advance) with $\mathrm{Cu} \mathrm{K} \alpha$ radiation, $\lambda=1.542 \AA$. The specific surface area was calculated by the Bruner-Emmett-Teller (BET) method. The pore size distributions were derived from the adsorption branches of the isotherms based on the Barrett-Joyner-Hollande $(\mathrm{BJH})$ model. Magnetic hysteresis loops at room temperature were obtained using a vibrating sample magnetometer VSM 7304 (Lakeshore, Columbus, OH, USA). The chemical composition of nanocomposites was characterized by XPS (U.S. Thermos Scientific ESCALAB250). The UV-Vis spectra (China, Shanghai, Shimadzu UV-2501 PC spectrometer) were performed to study the catalytic reduction activity. The samples were placed in a $1 \times 1 \times 3 \mathrm{~cm}$ quartz cuvettes, and the spectra were recorded at room temperature.

\subsection{Preparation of $\mathrm{CuFe}_{2} \mathrm{O}_{4} / \mathrm{CNC}$ Nanocomposites}

In a typical preparation, the procedure was reported as per previous research [12]. CNC (0.2 g) was dispersed in $40 \mathrm{~mL}$ of glycol with vigorous stirring in an ultrasonic generator for $0.5 \mathrm{~h}$. On the other hand, $1.6 \mathrm{mmol} \mathrm{CuCl} 2 \cdot 2 \mathrm{H}_{2} \mathrm{O}$ and $3.2 \mathrm{mmol} \mathrm{FeCl} \cdot 6 \mathrm{H}_{2} \mathrm{O}$ were dissolved in $20 \mathrm{~mL}$ of glycol to form a clear solution. After complete dissolution, $\mathrm{CNC}$ solution was poured into the metal precursor solution and followed by the addition of $0.2 \mathrm{~g}$ PVP while stirring for $0.5 \mathrm{~h}$. Addition of $\mathrm{NH}_{4} \mathrm{OAc}$ (90 $\mathrm{mmol}$ ) in a stepwise manner was done to the mixture until homogeneous light green dispersion. Then, the mixture was transferred into a Teflon-lined stainless steel autoclave (80 mL capacity) and heated at $200{ }^{\circ} \mathrm{C}$ for $11 \mathrm{~h}$. After the reaction, the autoclave was naturally cooled to room temperature, 
and the catalysts were collected and washed with redistilled water and ethanol three times, respectively. Finally, the catalysts were dried in a vacuum for $4 \mathrm{~h}$ at $60^{\circ} \mathrm{C}$.

\subsection{In Situ Reduction of $A g^{+}$Ions}

To coat $\mathrm{CuFe}_{2} \mathrm{O}_{4} / \mathrm{CNC}$ nanocomposites with the PDA shell, $50 \mathrm{mg} \mathrm{CuFe} \mathrm{O}_{4} / \mathrm{CNC}$ nanocomposites and $50 \mathrm{mg}$ of dopamine hydrochloride were dissolved in $25 \mathrm{~mL}$ Tris buffer solution $(10 \mathrm{mM}, \mathrm{pH}=8.5)$. After shaking for $3 \mathrm{~h}$ at room temperature, the $\mathrm{CuFe}_{2} \mathrm{O}_{4} / \mathrm{CNC@PDA}$ were separated and washed with ultrapure water and ethanol several times. For the preparation of Ag NPs on PDA surfaces, Tollen's reagent (silver ammonia solution) was used as the Ag precursor solution. Silver ammonia solution was prepared by adding ammonia aqueous solution ( $2 \mathrm{wt} \%$ ) into $10 \mathrm{mg} \cdot \mathrm{mL}^{-1} \mathrm{AgNO}_{3}$ solution until brown precipitation was just dissolved. Portions $50 \mathrm{mg}$ in size of the $\mathrm{CuFe}_{2} \mathrm{O}_{4} / \mathrm{CNC} @ \mathrm{PDA}$ nanocomposites were added to $25 \mathrm{~mL}$ of silver ammonia solution, and the mixture was shaken in a rotary shaker for $6 \mathrm{~h}$ at room temperature. The products were collected, washed with ultrapure water and ethanol several times, and dried under vacuum. Then, $\mathrm{CuFe}_{2} \mathrm{O}_{4} / \mathrm{CNC} @ \mathrm{Ag}$ nanocomposites were obtained.

\subsection{Preparation of $\mathrm{CuFe}{ }_{2} \mathrm{O}_{4} / \mathrm{CNC} @ A g @ Z I F-8$ Nanocomposites}

Briefly, $50 \mathrm{mg} \mathrm{CuFe} \mathrm{O}_{4} / \mathrm{CNC@Ag} \mathrm{nanocomposites} \mathrm{were} \mathrm{added} \mathrm{into} \mathrm{Zn}\left(\mathrm{NO}_{3}\right)_{2} \cdot 6 \mathrm{H}_{2} \mathrm{O}$ methanol solution $(10 \mathrm{~mL}, 50 \mathrm{mM})$ and stirred for $10 \mathrm{~min}$ at $50{ }^{\circ} \mathrm{C}$. Subsequently, the nanocomposites were dispersed in methanol solution $(10 \mathrm{~mL}, 500 \mathrm{mM})$ under stirring for $30 \mathrm{~min}$ at $50{ }^{\circ} \mathrm{C}$, collected by a magnet, cleaned with ultrapure water and ethanol, and dried under vacuum at $60^{\circ} \mathrm{C}$ overnight.

\subsection{General Procedure for the Reduction of 4-NP}

The reduction of 4-NP by $\mathrm{NaBH}_{4}$ was chosen as a model reaction for investigating the catalytic performance of the $\mathrm{CuFe}_{2} \mathrm{O}_{4} / \mathrm{CNC}, \mathrm{CuFe}_{2} \mathrm{O}_{4} / \mathrm{CNC} @ \mathrm{Ag}$, and $\mathrm{CuFe} \mathrm{O}_{4} / \mathrm{CNC@Ag@ZIF-8}$ nanocomposites. Typically, $2.35 \mathrm{~mL}$ ultrapure water, $200 \mu \mathrm{L} 5 \mathrm{mM} 4$-NP solution, and $450 \mu \mathrm{L} 200 \mathrm{mM}$ of fresh prepared $\mathrm{NaBH}_{4}$ aqueous solution were added into standard quartz cuvettes respectively, and the solutions turned bright yellow rapidly. Subsequently, $3 \mathrm{mg}$ of each catalysts was added to start the reaction, and the intensity of the absorption peak at $400 \mathrm{~nm}$ was monitored by UV-Vis spectroscopy as a function of time.

\section{Conclusions}

In summary, we demonstrated an effective strategy for the fabrication of novel cellulose nanocrystals (CNC)-supported magnetic $\mathrm{CuFe}_{2} \mathrm{O}_{4} @ \mathrm{Ag} @ Z \mathrm{ZIF}-8$ catalysts which consist of a paramagnetic $\mathrm{CuFe}_{2} \mathrm{O}_{4} @ \mathrm{Ag}$ core and a porous ZIF-8 shell. The use of CNC include being a template and dispersant for the incorporation with $\mathrm{CuFe}_{2} \mathrm{O}_{4}$ NPs and a good absorbent via $\pi-\pi$ stacking interactions of 4-NP. The framework matrix of the resulting composites retains its high surface areas, uniform mesoporous structure, porous crystalline structure, and good magnetic response. The core-shell magnetic catalysts were found to exhibit excellent catalytic performance for 4-nitrophenol reduction with good reusability. Compared to $\mathrm{CuFe}_{2} \mathrm{O}_{4} / \mathrm{CNC} @ \mathrm{Ag}$ catalysts, the core-shell structure $\mathrm{CuFe}_{2} \mathrm{O}_{4} / \mathrm{CNC} @ \mathrm{Ag} @ Z \mathrm{ZIF}-8$ nanocomposites are ideal recyclable catalysts for liquid-phase reductions due to a porous ZIF-8 shell for stabilization of the encapsulated Ag NPs and rapid adsorption of chemical pollutants from aqueous solution. More importantly, with the merits of easy separation and porous shell structure, this simple and versatile method might provide a multitude of noble, ZIF-8, and magnetic catalysts for broad applications, such as environmental protection, chemical biosensors, and so on.

Author Contributions: Conceptualization, S.Z. and Y.X.; methodology, S.Z. and D.Z.; data curation, W.C. and H.L.; writing - review and editing, D.Z. and C.H. All authors have read and agreed to the published version of the manuscript.

Funding: This research was funded by the Key Scientific Research Plan of Shaanxi Provincial Education Department (number 17JS016), the Guangxi Key Laboratory of Clean Pulping, the Papermaking and Pollution 
Control Opening Fund (KF 201711) and the National Demonstration Center for Experimental Light Chemistry Engineering Education (2018QGSJ02-09).

Conflicts of Interest: The authors declare no conflict of interest.

\section{References}

1. Leung, K.C.; Xuan, S.; Zhu, X. Gold and iron oxide hybrid nanocomposite materials. Chem. Soc. Rev. 2012, 41, 1911-1928. [CrossRef]

2. Deng, Y.; Li, E.; Cheng, X.; Zhu, J.; Lu, S.; Ge, C.; Pan, Y.; Gu, H. Facile preparation of hybrid core-shell nanorods for photo thermal and radiation combined therapy. Nanoscale 2016, 8, 3895-3899. [CrossRef] [PubMed]

3. Li, J.X.; Zou, M.Z.; Wen, W.W.; Zhao, Y.Y.; Lin, B.; Chen, L.Z.; Lai, H.; Guan, L.H.; Huang, Z.G. Spinel $\mathrm{MFe}_{2} \mathrm{O}_{4}$ $(\mathrm{M}=\mathrm{Co}, \mathrm{Ni})$ nanoparticles coated on multi-walled carbon nanotubes as electrocatalysts for $\mathrm{Li}_{2} \mathrm{O}_{2}$ batteriesm. J. Mater. Chem. A 2014, 2, 10257-10262. [CrossRef]

4. Su, L.; Qin, W.J.; Zhang, H.; Rahman, Z.U.; Ren, C.L.; Ma, S.; Chen, X. The peroxidase/catalase-like activities of $\mathrm{MFe}_{2} \mathrm{O}_{4}(\mathrm{M}=\mathrm{Mg}, \mathrm{Ni}, \mathrm{Cu}) \mathrm{MNPs}$ and their application in colorimetric biosensing of glucose. Biosens. Bioelectron. 2015, 63, 384-391. [CrossRef] [PubMed]

5. Ke, F.; Wang, L.; Zhu, J. Multifunctional Au-Fe ${ }_{3} \mathrm{O}_{4} @ \mathrm{MOF}$ core-shell nanocomposite catalysts with controllable reactivity and magnetic recyclability. Nanoscale 2014, 7, 1201-1208. [CrossRef]

6. Ma, R.; Yang, P.; Ma, Y. Facile synthesis of magnetic hierarchical core-shell structured $\mathrm{Fe}_{3} \mathrm{O}_{4} @ P D A-P d @ M O F$ nanocomposites: Highly integrated multifunctional catalysts. Chemcatchem Catal. 2018, 10, 446-1454.

7. Zheng, J.; Dong, Y.; Wang, W. In situ loading of gold nanoparticles on $\mathrm{Fe}_{3} \mathrm{O}_{4} @ \mathrm{SiO}_{2}$ magnetic nanocomposites and their high catalytic activity. Nanoscale 2013, 5, 4894-4901. [CrossRef]

8. Chook, S.W.; Yau, S.X.; Chia, C.H.; Chin, S.X.; Zakaria, S. Carboxylated nanoncellulose as a template for the synthesis of silver nanoprism. Appl. Surf. Sci. 2017, 422, 32-38. [CrossRef]

9. Ullah, M.W.; Ul-Islam, M.; Khan, S.; Kim, Y.; Park, J.K. Innovative production of bio-cellulose using a cell-free system derived from a single cell line. Carbohydr. Polym. 2015, 132, 286-294. [CrossRef]

10. Zhang, J.; Choi, Y.S.; Yoo, C.G.; Kim, T.H.; Brown, R.C.; Shanks, B.H. Cellulose-hemicellulose and cellulose-lignin interactions during fast pyrolysis. Acs Sustain. Chem. Eng. 2015, 3, 293-301. [CrossRef]

11. Kaushik, M.; Li, A.Y.; Hudson, R.; Masnadi, M.; Li, C.J.; Moores, A. Reversing aggregation: Direct synthesis of nanocatalysts from bulk metal. Cellulose nanocrystals as active support to access efficient hydrogenation silver nanocatalysts. Green Chem. 2016, 18, 129-133. [CrossRef]

12. Zhang, S.F.; Zhao, D.Y.; Hou, C.; Li, H.; Liang, C. Facile one-pot synthesis of cellulose nanocrystal-supported hollow $\mathrm{CuFe}_{2} \mathrm{O}_{4}$ nanoparticles as efficient catalyst for 4-nitrophenol reduction. J. Nanopart. Res. 2018, 20, 161. [CrossRef]

13. Gawande, M.B.; Branco, P.S.; Varma, R.S. Nano-magnetite $\left(\mathrm{Fe}_{3} \mathrm{O}_{4}\right)$ as a support for recyclable catalysts in the development of sustainable methodologies. Chem. Soc. Rev. 2013, 42, 3371-3393. [CrossRef] [PubMed]

14. Wu, L.; Mendoza-Garcia, A.; Li, Q.; Sun, S. Organic phase syntheses of magnetic nanoparticles and their applications. Chem. Rev. 2016, 116, 10473-10512. [CrossRef] [PubMed]

15. Xiong, R.; Lu, C.; Wang, Y.; Zhou, Z.H.; Zhang, X. Nanofibrillated cellulose as the support and reductant for the facile synthesis of $\mathrm{Fe}_{3} \mathrm{O}_{4} / \mathrm{Ag}$ nanocomposites with catalytic and antibacterial activity. J. Mater. Chem. A 2013, 1, 14910-14918. [CrossRef]

16. Zhong, Y.; Ni, Y.; Li, S. Chain-like $\mathrm{Fe}_{3} \mathrm{O}_{4} @$ resorcinol-formaldehyde resins Ag composite microstructures: Facile construction and applications in antibacterial and catalytic fields. Rsc Adv. 2016, 6, 15831-15837. [CrossRef]

17. Shokouhimehr, M.; Shin, K.Y.; Lee, J.S.; Hackett, M.J.; Jun, S.W.; Oh, M.H.; Hyeon, T.; Jang, J. Magnetically recyclable core-shell nanocatalysts for efficient heterogeneous oxidation of alcohols. J. Mater. Chem. A 2014, 2, 7593-7599. [CrossRef]

18. Zhang, J.; Fang, Q.; Duan, J. Magnetically separable nanocatalyst with the $\mathrm{Fe}_{3} \mathrm{O}_{4}$ core and polydopamine-sandwiched Au nanocrystal shell. Langmuir 2018, 34, 4298-4306. [CrossRef]

19. Rasaki, S.A.; Zhao, C.; Wang, R.; Wang, J.; Jiang, H.; Yang, M. Facile synthesis approach for preparation of robust and recyclable $\mathrm{Ag} / \mathrm{ZnO}$ nanorods with high catalytic activity for 4-nitrophenol reduction. Mater. Res. Bull. 2019, 119, 110536. [CrossRef] 
20. Yan, F.; Sun, R. Facile synthesis of bifunctional Fe3O4/Au nanocomposite and their application in catalytic reduction of 4-nitrophenol. Mater. Res. Bull. 2014, 57, 293-299. [CrossRef]

21. Chen, Y.; Chen, S.; Wang, B.; Yao, J.; Wang, A. TEMPO-oxidized bacterial cellulose nanofibers-supported gold nanoparticles with superior catalytic properties. Carbohydr. Polym. 2017, 160, 34-42. [CrossRef]

22. Chen, L.; Wang, H.; Liu, C. One-pot achieving well-dispersed copper nanoparticles on N-doped carbon films. J. Alloy. Compd. 2016, 656, 622-627. [CrossRef]

23. Wu, X.D.; Lu, C.H.; Zhang, W.; Yuan, G.P.; Xiong, R.; Zhang, X.X. A novel reagentless approach for synthesizing cellulose nanocrystal-supported palladium nanoparticles with enhanced catalytic performance. J. Mater. Chem. A 2013, 1, 8645-8652. [CrossRef]

24. Wu, M.L.; Li, Y.Y.; Yue, R.; Zhang, X.D.; Huang, Y.M. Removal of silver nanoparticles by mussel-inspired $\mathrm{Fe}_{3} \mathrm{O}_{4} @$ polydopamine core-shell microspheres and its use as efficient catalyst for methylene blue reduction. Sci. Rep. 2017, 7, 42773. [CrossRef] [PubMed]

25. Das, P.; Yuran, S.; Yan, J.; Lee, P.S.; Reches, M. Sticky tubes and magnetic hydrogels co-assembled by a short peptide and melanin-like nanoparticles. Chem. Commun. 2015, 51, 5432-5435. [CrossRef] [PubMed]

26. Yan, Y.H.; Zheng, Z.F.; Deng, C.H.; Zhang, X.M.; Yang, P.Y. Facile synthesis of $\mathrm{Ti}^{4+}$-immobilized $\mathrm{Fe}_{3} \mathrm{O}_{4} @$ polydopamine core-shell microspheres for highly selective enrichment of phosphopeptides. Chem. Commun. 2013, 49, 5055-5057. [CrossRef]

27. Ryou, M.H.; Kim, J.B.; Lee, I.H.; Kim, S.J.; Jeong, Y.K.; Hong, S.K.; Choi, J.W.; Ryu, J.H.; Lee, H.; Kim, T.S.; et al. Mussel-inspired adhesive binders for high-performance silicon nanoparticle anodes in lithium-ion batteries. Adv. Mater. 2013, 25, 1571-1576. [CrossRef]

28. Huang, Y.Q.; Liu, Y.J.; Yang, Z.H.; Jia, J.L.; Li, X.; Luo, Y.; Fang, Y. Synthesis of yolk/shell $\mathrm{Fe}_{3} \mathrm{O}_{4}$-polydopamine-graphene-Pt nanocomposite with high electro catalytic activity for fuel cells. $J$. Power Sources 2014, 246, 868-875. [CrossRef]

29. Zeng, T.; Zhang, X.L.; Niu, H.Y.; Ma, Y.R.; Li, W.H.; Cai, Y.Q. In situ growth of gold nanoparticles onto polydopamine-encapsulated magnetic microspheres for catalytic reduction of nitrobenzene. Appl. Catal. B 2013, 134, 26-33. [CrossRef]

30. Wu, X.Y.; Shi, Z.Q.; Fu, S.D.; Chen, J.L.; Berry, R.M.; Tam, K.C. Strategy for synthesizing porous cellulose nanocrystal supported metal nanocatalysts. Acs Sustain. Chem. Eng. 2016, 4, 5929-5935. [CrossRef]

31. Han, Y.; Wu, X.; Zhang, X.; Zhou, Z.; Lu, C. Dual functional biocomposites based on polydopamine modified cellulose nanocrystal for $\mathrm{Fe}^{3+}$-pollutant detecting and autoblocking. ACS Sustain. Chem. Eng. 2016, 4, 5667-5673. [CrossRef]

32. Tang, J.; Song, Y.; Tanvir, S.; Anderson, W.A.; Berry, R.M.; Tam, K.C. Polyrhodanine coated cellulose nanocrystals: A sustainable antimicrobial agent. ACS Sustain. Chem. Eng. 2015, 3, 1801-1809. [CrossRef]

33. Jiang, H.L.; Akita, T.; Ishida, T.; Haruta, M.; Xu, Q. Synergistic catalysis of Au@Ag core-shell nanoparticles stabilizedon metal-organic framework. J. Am. Chem. Soc. 2011, 133, 1304-1306. [CrossRef] [PubMed]

34. Li, P.; Zeng, H.C. Immobilization of metal-organic framework nanocrystals for advanced design of supported nanocatalysts. ACS Appl. Mater. Interfaces 2016, 8, 29551-29564. [CrossRef]

35. Zeng, T.; Zhang, X.; Wang, S. Spatial confinement of $\mathrm{a} \mathrm{Co}_{3} \mathrm{O}_{4}$ catalyst in hollow metal-organic frameworks as a nanoreactor for improved degradation of organic pollutants. Environ. Sci. Technol. 2015, 49, 2350-2357. [CrossRef]

36. Zhou, J.J.; Wang, P.C.; Wang, X.; Goh, Y.T.; Fang, Z.; Messersmith, P.B.; Duan, H. Versatile core-shell nanoparticle@metal-organic framework nanohybrids: Exploiting mussel-inspired polydopamine for tailored structural integration. ACS Nano 2015, 9, 6951-6960. [CrossRef]

37. Cao, E.J.; Duan, W.Z.; Wang, F.; Wang, A.Q.; Zheng, Y. Natural cellulose fiber derived hollow-tubular-orientedpolydopamine: In-situ formation of Ag nanoparticles for reduction of 4-nitrophenol. Carbohydr. Polym. 2017, 158, 44-50. [CrossRef]

38. An, X.Y.; Long, Y.D.; Ni, Y.H. Cellulose nanocrystal/hexadecyl-trimethyl ammonium bromide/silvernanoparticle composite as a catalyst for reduction of 4-nitrophenol. Carbohydr. Polym. 2017, 156, 253-258. [CrossRef]

39. Zhang, H.; Zhao, Y.; Liu, W.; Gao, S.T.; Shang, N.Z.; Wang, C.; Wang, Z. Preparation of magnetically separable $\mathrm{Cu}_{6 / 7} \mathrm{Co}_{1 / 7} \mathrm{Fe}_{2} \mathrm{O}_{4}$-graphene catalyst and its application in selective reduction of nitroarenes. Catal. Commun. 2015, 59, 161-165. [CrossRef] 
40. Liu, Y.; Zhang, Y.Y.; Kou, Q.W.; Chen, Y.; Han, D.L.; Wang, D.D.; Lu, Z.Y.; Chen, L.; Yang, J.H.; Xing, S. Eco-friendly seeded $\mathrm{Fe}_{3} \mathrm{O}_{4}$-Ag nanocrystals: A new type of highly efficient and low cost catalyst for methylene blue reduction. RSC Adv. 2018, 8, 2209-2218. [CrossRef]

41. Dandia, A.; Jain, A.K.; Sharma, S. $\mathrm{CuFe}_{2} \mathrm{O}_{4}$ nanoparticles as a highly efficient and magnetically recoverable catalyst for the synthesis of medicinally privileged spiropyrimidine scaffolds. RSC Adv. 2013, 3, 2924-2934. [CrossRef]

42. Zhang, X.; Feng, M.; Qu, R.; Liu, H.; Wang, L.; Wang, Z. Catalytic degradation of diethyl phthalate in aqueous solution by persulfate activated with nano-scaled magnetic $\mathrm{CuFe}_{2} \mathrm{O}_{4} / \mathrm{MWCNTs}$. Chem. Eng. J. 2016, 301, 1-11. [CrossRef]

43. Hu, Z.; Meng, Q.; Liu, R.; Fu, S.Y.; Lucia, L.A. Physical study of the primary and secondary photo thermal events in gold/cellulose nanocrystals (Au NP/CNC) nanocomposites embedded in PVA matrices. ACS Sustain. Chem. Eng. 2017, 5, 1601-1609. [CrossRef]

44. Chen, G.Y.; Yu, H.Y.; Zhang, C.H. A universal route for the simultaneous extraction and functionalization of cellulose nanocrystals from industrial and agricultural celluloses. J. Nanopart. Res. 2016, 18, 48-62. [CrossRef]

45. Yang, Y.; Wang, J.C.; Wu, F.C.; Ye, G.; Yi, R.; Lu, Y.X. Surface-initiated SET-LRP mediated by mussel-inspired polydopamine chemistry for controlled building of novel core-shell magnetic nanoparticles for highly-efficient uranium enrichment. Polym. Chem. 2016, 7, 2427-2435. [CrossRef]

46. Han, P.P.; Jiang, Z.Y.; Wang, X.L.; Wang, X.Y.; Zhang, S.H.; Shi, J.F.; Wu, H. Facile preparation of porous magnetic polydopamine microspheres through an inverse replication strategy for efficient enzyme immobilization. J. Mater. Chem. B 2015, 3, 7194-7202. [CrossRef]

47. Zhang, T.; Zhang, X.; Yan, X. Synthesis of $\mathrm{Fe}_{3} \mathrm{O}_{4} @ Z I F-8$ magnetic core-shell microspheres and their potential application in a capillary microreactor. Chem. Eng. J. 2013, 228, 398-404. [CrossRef]

48. Zou, Z.; Wang, S.; Jia, J.; Xu, F.; Long, Z.; Hou, X. Ultrasensitive determination of inorganic arsenic by hydride generation-atomic fluorescence spectrometry using $\mathrm{Fe}_{3} \mathrm{O}_{4} @ Z$ ZIF-8 nanoparticles for preconcentration. Microchem. J. 2015, 124, 578-583. [CrossRef]

49. Alshehria, S.M.; Almuqatia, T.; Almuqatib, N.; Al-Farraja, E.; Alhokbanya, N.; Ahamada, T. Chitosan based polymer matrix with silver nanoparticles decorated multiwalled carbon nanotubes for catalytic reduction of 4-nitrophenl. Carbohydr. Polym. 2016, 151, 135-143. [CrossRef]

50. Zarringhadam, P.; Farhadi, S. Flower-like $\mathrm{Bi}_{2} \mathrm{O}_{2} \mathrm{CO}_{3} / \mathrm{NiFe}_{2} \mathrm{O}_{4}$, magnetically recoverable nanocomposites: Preparation, characterization and their catalytic application in the reduction of 4-nitrophenol to 4-aminophenol. J. Alloy. Compd. 2017, 729, 1046-1057. [CrossRef]

51. Lu, W.B.; Ning, R.; Qin, X.Y.; Zhang, Y.W.; Chang, G.H.; Liu, S.; Luo, Y.L.; Sun, X.P. Synthesis of Au nanoparticles decorated graphene oxide nanosheets: Noncovalent functionalization by TWEEN 20 in situ reduction of aqueous chloroaurate ions for hydrazine detection and catalytic reduction of 4-nitrophenol. J. Hazard. Mater. 2011, 197, 320-326. [CrossRef] [PubMed]

52. Zhou, N.; Polavarapu, L.; Wang, Q.; Xu, Q. Mesoporous $\mathrm{SnO}_{2}$-Coated Metal Nanoparticles with Enhanced Catalytic Efficiency. ACS Appl. Mater. Interfaces 2015, 7, 4844-4850. [CrossRef] [PubMed]

53. Pach, P.; Kandambeth, S.; Díaz, D.D.; Banerjee, R. Highly stable covalent organic framework-Au nanoparticles hybrids for enhanced activity for nitrophenol reduction. Chem. Commun. 2014, 50, 3169-3172.

54. Chi, Y.; Tu, J.; Wang, M.; Li, X. One-pot synthesis of ordered mesoporous silver nanoparticle/carbon composites for catalytic reduction of 4-nitrophenol. J. Colloid Interface Sci. 2014, 423, 54-59. [CrossRef] [PubMed]

55. Wang, T.; Ma, B.; Jin, A. Facile loading of Ag nanoparticles onto magnetic microsphere by the aid of a tannic acid-metal polymer layer to synthesize magnetic disinfectant with high antibacterial activity. J. Hazard. Mater. 2017, 342, 392-400. [CrossRef] [PubMed]

56. Zhang, K.; Wang, C.; Rong, Z. Silver coated magnetic microflowers as an efficient and recyclable catalyst for catalytic reduction. New J. Chem. 2017, 41, 14199-14208. [CrossRef] 
57. Shi, X.; Yao, Y.; Xu, Y. Imparting catalytic activity to a covalent organic framework material by nanoparticle encapsulation. ACS Appl. Mater. Interfaces 2017, 9, 7481-7488. [CrossRef]

Sample Availability: Samples of the compounds are unavailable from the authors. 